\title{
Post-mortem persistence of SARS-CoV-2: a preliminary study
}

\author{
Sara Sablone ${ }^{1} \cdot$ Biagio Solarino $^{1} \cdot$ Davide Ferorelli $^{1} \cdot$ Marcello Benevento $^{1} \cdot$ Maria Chironna $^{2} \cdot$ Daniela Loconsole $^{2}$. \\ Anna Sallustio ${ }^{2} \cdot$ Alessandro Dell'Erba $^{1} \cdot$ Francesco Introna $^{1}$
}

Accepted: 4 April 2021 / Published online: 8 May 2021

(C) The Author(s) 2021

\begin{abstract}
Since the beginning of March 2020, the severe acute respiratory syndrome coronavirus 2 (SARS-CoV-2) pandemic has been the cause of millions of deaths worldwide. The need to better define the pathogenesis of coronavirus disease 19 (Covid-19) as well as to provide the correct statistical records concerning deaths related to this virus, inevitably involves the role of forensic pathology and routine autopsy practice. Currently, some data on macroscopic and microscopic features in autopsies performed in suspected Covid-19 cases are reported in the literature. The persistence of SARS-CoV-2 in cadavers has not yet been elucidated and only a few reports have emphasized the importance of evaluating the Virus RNA in post-mortem tissues. In this preliminary study, we observed that SARS-CoV-2 survives in multiple cadaver tissues many days after death despite some extreme conditions of post-mortem body preservation. The results of this on-going analysis could help improve the safety of working practices for pathologists as well as understanding the possible interaction between microbiological agents and the cadaver tissue's supravital reactions.
\end{abstract}

Keywords SARS-CoV-2 $\cdot$ Viral RNA $\cdot$ Cadaver tissue samples $\cdot$ Post-mortem interval $\cdot$ COVID-19 autopsy

\section{Introduction}

SARS-CoV-2 has caused millions of deaths worldwide. Globally, new COVID-19 cases and deaths have continued to increase to approximately 4.6 million new cases and about 79000 new deaths every week. This brings the cumulative number to over 75 million reported cases and 1.6 million deaths globally since the start of the pandemic [1].

In the living, the virus spreads through respiratory droplets and the conjunctival and bronchial epithelium are mentioned as portals for infection [2]. SARS CoV-2 Ribonucleic Acid (RNA) detection on respiratory specimens is considered the gold standard for diagnosing the infection. Bilateral pneumonia progressing to acute respiratory distress syndrome (ARDS) represents the most often

Biagio Solarino

biagio.solarino@uniba.it

1 Section of Legal Medicine, Department of Interdisciplinary Medicine, Bari Policlinico Hospital, University of Bari, 70124 Bari, Italy

2 Section of Hygiene, Department of Biomedical Sciences and Human Oncology, Bari Policlinico Hospital, University of Bari, 70124 Bari, Italy reported SARS-CoV-2 related cause of death. Against this backdrop, autopsy practice has a fundamental role in better defining the pathogenesis of SARS-CoV-2 related disease and providing accurate epidemiological data upon confirmed Covid-19 death cases [3].

From a forensic pathology standpoint, only a few articles have focused on macroscopic features and microscopic findings in those who have died from SARS-CoV-2 infections.

The virus risk of transmission is alleged even in autopsy routine practice, and international societies proposed to classify SARS-CoV-2 in risk group 3 [4].

Currently, no virus infections in forensic pathologists or medical staff involved in mortuary or autopsy practice have been reported in the literature. This means that if appropriate protective measures are followed, an increased risk of transmission is not expected in these professions [5].

Though the persistence of human coronaviruses on inanimate surfaces has been seen for up to nine days [6], the evidence of SARS-CoV-2 in cadavers is still a matter under discussion. Beltempo and colleagues reported the persistence of SARS-CoV-2 RNA in respiratory swabs taken 35 days post-mortem. Therefore, a question arises about the detectability of the virus under particular conditions of postmortem body preservation [7]. 
With this in mind, we detected SARS-COV-2 RNA on samples taken on whole tissues of cadavers buried and/or frozen at minus $15{ }^{\circ} \mathrm{C}$ for many days before the autopsy. All the possible implications of these results will be discussed here.

\section{Materials and methods}

From October to December 2020, 5 judicial autopsies were performed at the Legal Medicine Unit of the Bari Hospital. Four of the cadavers were male and one was female. The ages ranged from 44 to 84 years (Mean: 63.8). The cause of death for 4 decedents was "Coronavirus 19-related bilateral pneumonia producing acute respiratory failure" (ICD10-CM: J12.82). In one case, it was "Polytrauma from suicidal precipitation in Covid affected patient" (ICD-10-CM: $\mathrm{X} 80)$.

In two cases, death occurred in the Emergency Department, in one case in the Intensive Care Unit, in another case at the Infectious Disease Unit, and another at home.

The time interval between the moment of death and the autopsy varied between 22 and 27 days. During this interval, the bodies underwent a period (from 20 to 25 days) in a refrigerator at a temperature of minus $15^{\circ} \mathrm{C}$. The bodies were allowed to reach room temperature before the autopsy. One cadaver was also buried for 5 days before being placed in the refrigerator. The main features are summarized in Table 1.

Before an anatomical examination, a sample extraction plan was made by consulting clinical pathologists, laboratory staff, and virologists. To standardize and record the sampling procedures, an autopsy checklist was prepared. Samples were taken directly after opening body cavities; organ and tissue cuttings were minimized (compatibly with investigative needs) to reduce infection risks. Post-mortem multifocal swabs were performed to gain samples of body fluids, while tissue blocks were collected and stored in $2 \mathrm{ml}-$ plastic test tubes (Eppendorf). As soon as the autopsies were over, all cadaveric samples were sent to the Laboratory of Molecular Epidemiology and Public Health of Hygiene Unit, Bari Hospital, to undergo molecular tests.

Molecular detection of viral RNA in cadaveric specimens was performed by extracting RNA from $5 \mu \mathrm{g}$ of tissue biopsy, preliminary overnight incubation in a lysis buffer RLT, and UTM (Copan, USA) swabs. Extraction was performed using the Nimbus platform (Hamilton, USA), and then PCR was performed using the Allplex TM 2019-nCoV assay (Seegene, South Korea) on the CFX96 (Bio-Rad, USA) in line with the manufacturer's instructions. The gene targets for the PCR assay were the $\mathrm{N}$ gene, the E gene, and the RdRP gene. An internal control provided assurance that specimens were successfully amplified and detected. The cycle threshold $(\mathrm{Ct})$ value was recorded for each of the 3 genes. Samples with a detected result for all 3 genes, or a single target gene, were interpreted as SARS Cov2 PCR positive, in line with the manufacturer's guidance.

Researchers in clinical studies have not validated the use of $\mathrm{Ct}$ to guide the management of COVID-19 cases. Indeed, $\mathrm{Ct}$ values from viral RNA can vary depending on the method of specimen collection, specimen source, transport, and the time from infection to collection to analysis. Additionally, no standard exists to validate quantitative assays that produce comparable results from labs and manufacturers.

Samples showing the amplification of the internal control but not the detection of the gene targets were classified as negative. Samples not showing the amplification of internal control were classified as invalid.

Table 1 Cadaver's principal features

\begin{tabular}{|c|c|c|c|c|c|c|}
\hline Case & Age & Sex & Cause of death & Place of death & $\begin{array}{l}\text { Interval death- } \\
\text { autopsy }\end{array}$ & Interval $\mathrm{T}^{\circ} \mathrm{C}$ (Days) \\
\hline 1 & 59 & M & $\begin{array}{l}\text { SARS-CoV-2 related bilateral pneu- } \\
\text { monia producing acute respiratory } \\
\text { failure }\end{array}$ & Intensive Care Unit & 22,5 days & $21\left(-15^{\circ} \mathrm{C}\right) ; 1,5$ (Room Temperature) \\
\hline 2 & 84 & M & $\begin{array}{l}\text { Polytrauma from suicidal precipita- } \\
\text { tion in Covid-affected patient }\end{array}$ & Home & 24,5 days & $23\left(-15^{\circ} \mathrm{C}\right) ; 1,5$ (Room Temperature) \\
\hline 3 & 68 & M & $\begin{array}{l}\text { SARS-CoV-2 related bilateral pneu- } \\
\text { monia producing acute respiratory } \\
\text { failure }\end{array}$ & Emergency Department & 23,5 days & $22\left(-15^{\circ} \mathrm{C}\right) ; 1,5$ (Room Temperature) \\
\hline 4 & 44 & $\mathrm{~F}$ & $\begin{array}{l}\text { SARS-CoV-2 related bilateral pneu- } \\
\text { monia producing acute respiratory } \\
\text { failure }\end{array}$ & Emergency Department & 26,5 days & $\begin{array}{l}5 \text { (Buried); } 20\left(-15^{\circ} \mathrm{C}\right) ; 1,5 \text { (Room } \\
\text { Temperature) }\end{array}$ \\
\hline 5 & 64 & M & $\begin{array}{l}\text { SARS-CoV-2 related bilateral pneu- } \\
\text { monia producing acute respiratory } \\
\text { failure }\end{array}$ & Emergency Department & 22,5 days & $21\left(-15^{\circ} \mathrm{C}\right) ; 1,5$ (Room Temperature) \\
\hline
\end{tabular}




\section{Results}

Some of the tested samples did not produce results due to the presence of inhibitory factors and we have indicated these with the acronym N/A (Not Assessed). The remaining samples provided results, which we expressed in terms of $\mathrm{Ct}$ (Cycle threshold). Ct refers to the number of cycles needed to amplify viral RNA to reach a detectable level. A high CT value might not be considered for accurate identification of the infectious potential of a patient [8-10].
We used $\mathrm{Ct}$ to indicate the positive outcome of the molecular tests on most of the analyzed samples, suggesting a multi-organ dissemination of Coronavirus- 2 .

We report the averages of the $\mathrm{CT}$ values obtained for each tissue sample analyzed in graphs (Figs. 1, 2, and 3).

Time from death to post-mortem examination ranged from 22 to 27 days. In one case, the body had also been buried for 5 days. Swabs were positive for SARS-CoV-2 by RT-PCR in all cases regardless of the timing of postmortem examination and even though the bodies had stayed
Fig. 1 Averages of the $\mathrm{N}$ Gene $\mathrm{Ct}$ values obtained for each tissue sample analyzed

\section{GENE N C(T)}

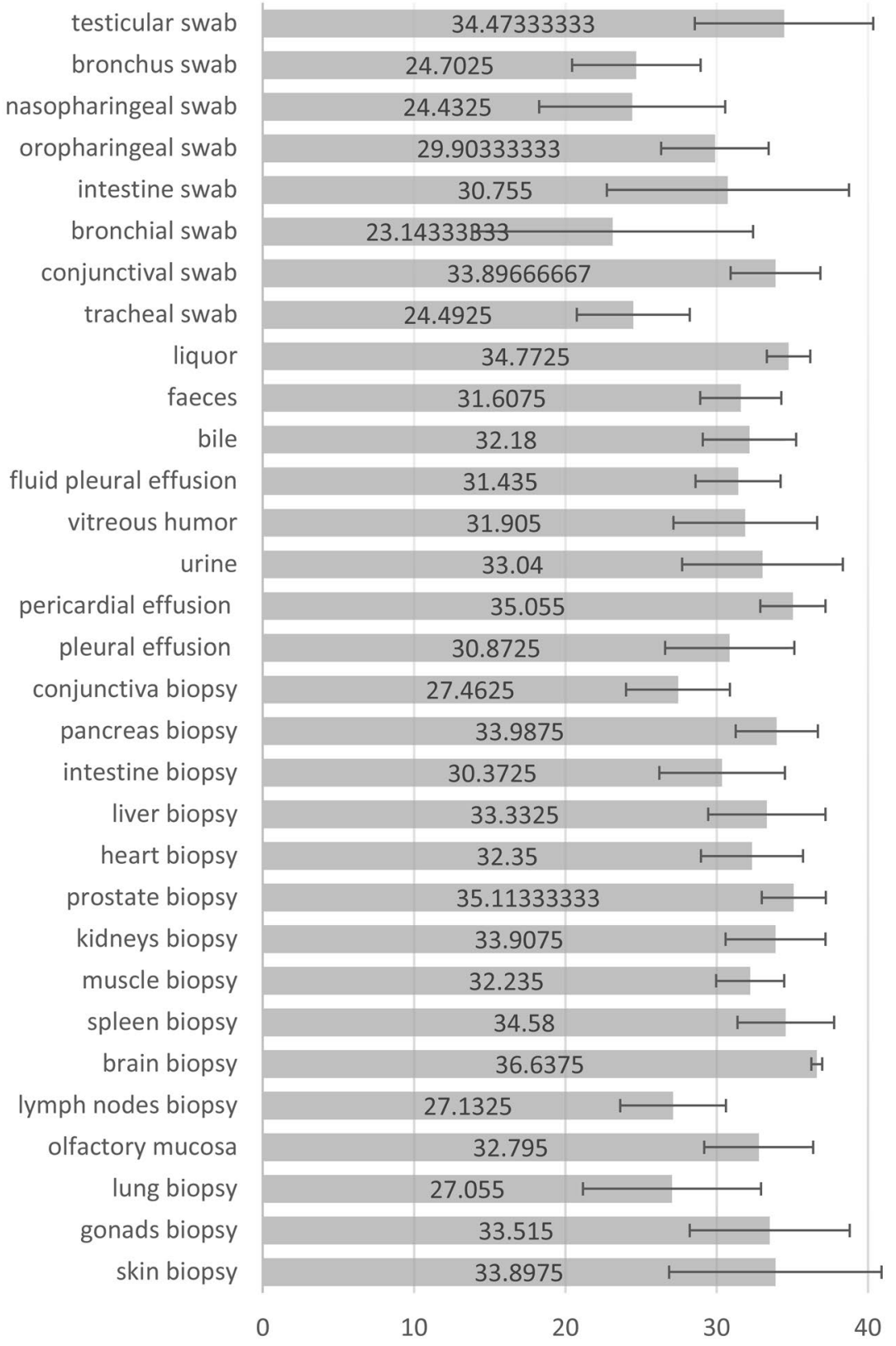


Fig. 2 Averages of the E Gene $\mathrm{Ct}$ values obtained for each tissue sample analyzed

\section{GENE E C(T)}

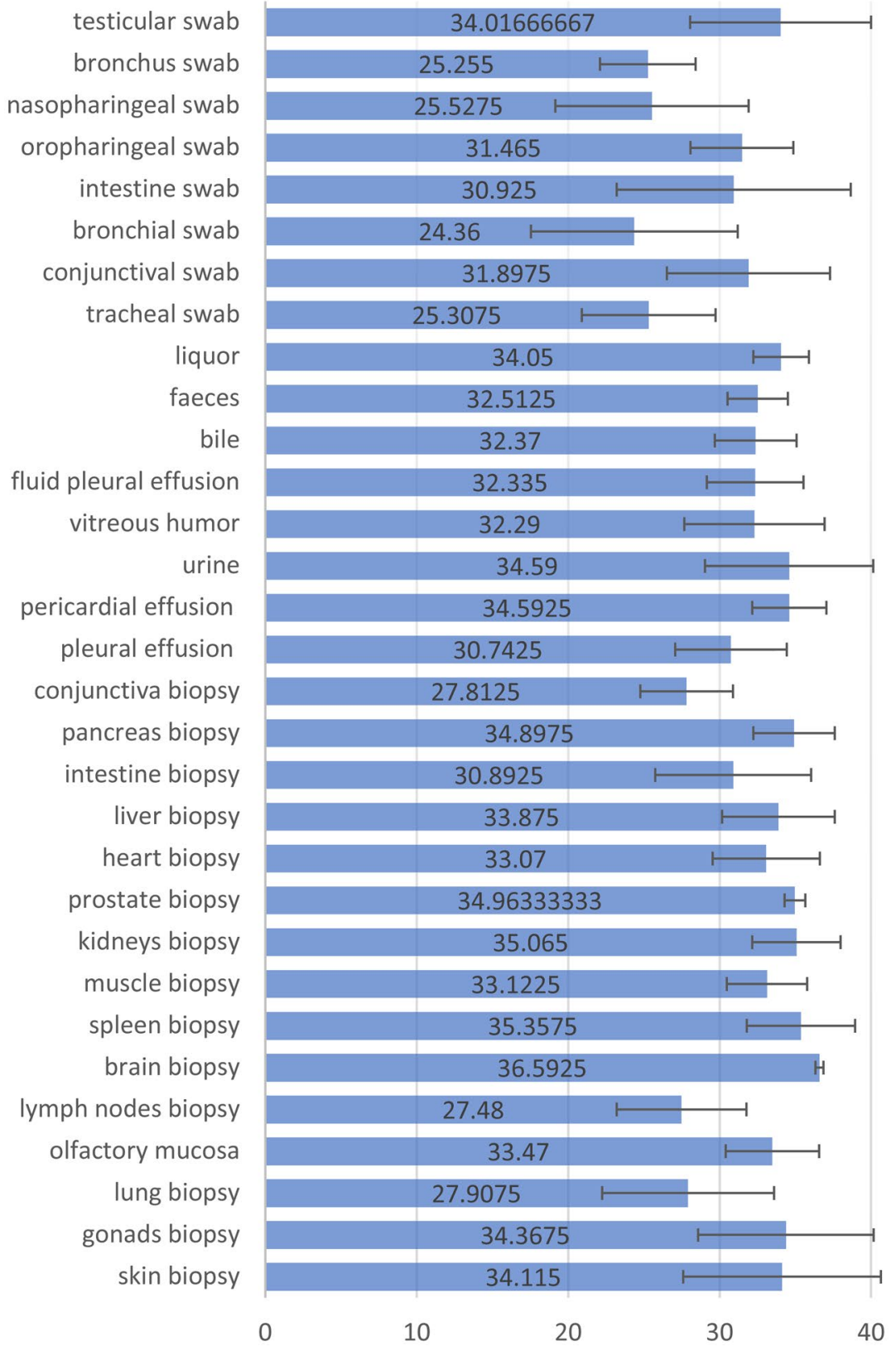

for several days in a cold room at $-15^{\circ} \mathrm{C}$ and one of them had previously been buried for 5 days.

\section{Discussion}

Coronavirus disease 2019 (COVID-19) is regarded as number three in the line of extremely infectious human coronavirus (such as the Severe Acute Respiratory Syndrome [SARS] and Middle East Respiratory Syndrome [MERS] coronaviruses) that have appeared over the last 20 years [11-13]. The unfolding of the novel COVID-19 pandemic has resulted in a significant burden on the global medical community, including autopsy activity [14, 15].

According to the World Health Organization (WHO), the transmission of severe acute respiratory syndrome coronavirus 2 (SARS-CoV-2) between individuals is through inhalation of sizeable respiratory droplets, fomites, and proximity with infected persons and facets [16]. Although, as at the time the WHO released its report in March 2020, there was no proof of people being infected as a result of exposure to COVID-19 related dead bodies [17], the suspected risk to 
Fig. 3 Averages of the RdRP Gene Ct values obtained for each tissue sample analyzed

\section{GENE RDRP/S C(T)}

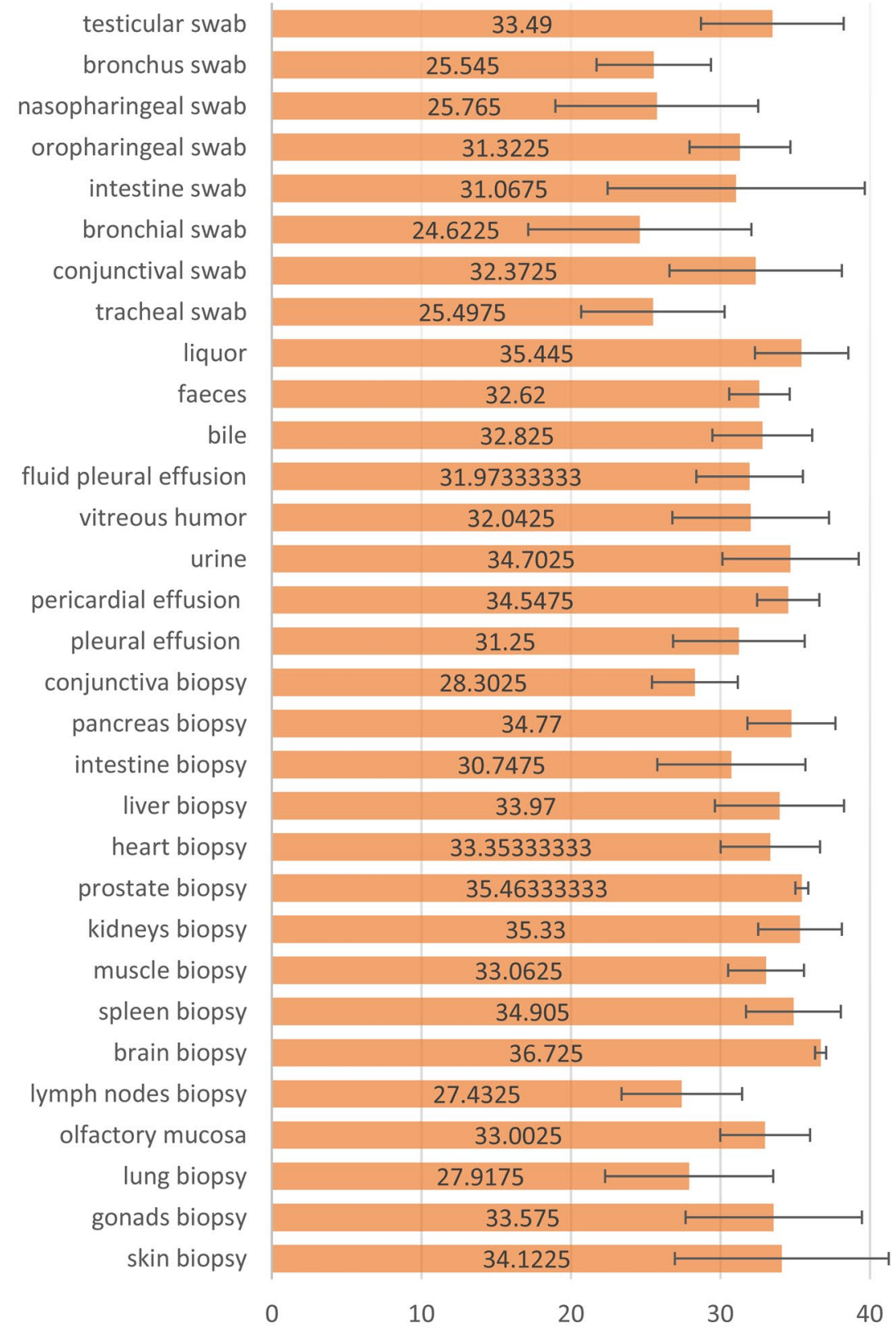

health professionals of COVID-19 infection from an individual whose death resulted from COVID-19 could not be overlooked.

For this reason, the Italian Ministry of Health issued a recommendation that in principle discourages the performing of autopsies on COVID-19 related bodies [18]. However, the autopsy is of great significance for elucidating the pathological changes, pathogenesis, and cause of death of Coronavirus Disease 2019 (COVID-19) and can provide a theoretical basis for prevention and control of the outbreak $[19,20]$. Moreover, the more we investigate SARS-CoV-2 ability to survive in different environments, the safer autopsies on individuals with COVID-19-related death will be.

According to the relevant literature, the majority of the microorganisms responsible for death also have a shorter life-span after the death of the host and therefore infection risk is minimized [21]. The higher risk that pathologists would be infected during the autopsy is generally attributed to common viral agents ( $\mathrm{HIV}, \mathrm{HBV}, \mathrm{HCV})$, mycobacterium tuberculosis, and the prions responsible for Transmissible Spongiphorme Encephalopathis [22]. Such pathogens are included in the infection Hazards Groups 3, where the risk 
to mortuary staff is minimal if standard safety autopsy procedures are applied [23].

Nonetheless, there is the possibility of an increase in the chances of disease transmission with direct exposure to body fluids and invasive procedures on the cadaver, such as procedures that generate droplets or aerosols [17, 24]. Soft tissues like the lungs of the cadaver could also be infectious if not handled properly during an autopsy [25]. Moreover, albeit less frequently, it is postulated that transmission may occur via the contamination of inanimate surfaces from an activated virus.

The SARS-CoV-2 virus has strong persistence in the external environment, especially at low temperatures. Kampf et al. supported the claim that human coronaviruses on inanimate surfaces could still be contagious at room temperature for about nine days [26]. However, this duration of persistence could be reduced at a temperature of $30{ }^{\circ} \mathrm{C}$ or higher. The WHO confirmed that human severe acute respiratory syndrome coronavirus 2 (SARS-CoV-2) could still be contagious on surfaces for as long as nine days [24].

According to a study on the resistance of severe acute respiratory syndrome coronavirus [27], the virus can survive for 2 days in hospitals or domestic sewage and dechlorinated tap water, for 3 days in feces, 14 days in normal saline, and 17 days in urine at $20^{\circ} \mathrm{C}$ away from light. However, at $4{ }^{\circ} \mathrm{C}$, the virus can survive longer than 14 days in the abovementioned water settings, and longer than 17 days in feces.

In a study conducted by Riddell et al. survival rates of SARS-CoV-2 were determined at different temperatures on common surfaces [28]. The authors obtained half-lives of between 1.7 and 2.7 days at $20^{\circ} \mathrm{C}$, reducing to a few hours when the temperature was elevated to $40{ }^{\circ} \mathrm{C}$. With initial viral loads broadly equivalent to the highest titres excreted by infectious patients, the viable virus was isolated for up to 28 days at $20{ }^{\circ} \mathrm{C}$ from common surfaces such as glass, stainless steel, and both paper and polymer banknotes. Conversely, infectious viruses survived less than $24 \mathrm{~h}$ at $40{ }^{\circ} \mathrm{C}$ on some surfaces.

Pagat et al. argued that heat (autoclave) and hypochlorites are effective in the decontamination of SARS-CoV [29], while other studies demonstrate that refrigeration may promote survival and persistence of coronaviruses $[24,30]$. It is also currently accepted that formalin fixation at room temperature inactivates SARS-CoV-2 within $24 \mathrm{~h}$ [31]. Moreover, the processes of paraffin embedding that occur at high temperature $\left(60-65{ }^{\circ} \mathrm{C}\right)$ seems to contribute to virus inactivation [32].

In human inanimate bodies, a report by Camero stated that people who had passed away from the novel COVID19 might still be contagious for hours or days [33]. In a series of 79 bodies examined by Heinrich et al. virus isolation by nasopharyngeal swabs was demonstrated up to $35 \mathrm{~h}$ post-mortem [34]. In a case report by Beltempo et al., the persistence of SARS-CoV-2 RNA in the upper respiratory tract of a patient dying with COVID-19 was documented 35-days after death [7].

In consideration, therefore, of the potential relevance of data generated by analysis of material obtained from postmortem examination, adopting the stricter safety procedures, we performed 5 complete autopsies with the main objective of verifying SARS-CoV-2 persistence in individuals whose death resulted from COVID-19 and whose cadavers were refrigerated at a temperature of $-15^{\circ}$ for a time interval between the moment of death and the autopsy which varied between 22 and 27 days. One of them had previously been buried for 5 days.

Our study demonstrates that a large amount of virus, which has a multiorgan distribution thanks to its tropism for many human organs and tissues, may remain in deceased people infected with SARS-CoV-2, and the survival time of the virus may even be prolonged in refrigerated cadavers thanks to its resistance to cold environments.

Thus, the performance of autopsies on infectious COVID19 bodies could be catastrophic for forensic pathologists and mortuary workers if the cadavers are not properly handled. As a rule in the COVID-19 pandemic, some invasive procedures in standard pathology autopsies, especially those methods that produce tiny-particles (such as using an oscillating saw or cleansing of intestines) should be discouraged. However, if it is necessary to perform any of the above procedures, full protection with necessary personal protective equipment (PPE) is vital [18, 35, 36].

In the light of the current COVID-19 pandemic, it is pertinent to ensure that COVID-19 safety protocols and standard operating procedures recommended for cadaveric dissections are strictly followed [37-40]. Besides, personal protective equipment (PPE) such as an impermeable disposable gown or overall, hand gloves, and face protectors (medical mask, shield, and goggles) should be provided for mortuary staff and other personnel that handle both the embalmed bodies and cadaver dissection [17, 25, 41].

\section{Conclusions}

The results of our study demonstrate that personal protection of examiners and disinfection of dissecting rooms, surroundings, and instruments should be taken seriously to avoid examiners being infected due to inadequate protection or careless operation.

At the same time, as the remains of patients who have died of COVID-19 may have a large amount of the virus, the prevention of infected bodies being accessible to relatives and speeding up the post-mortal procedures for burial is thoroughly justified. 
Our study demonstrates that SARS-CoV-2 infection is characterized by a multiorgan distribution as this coronavirus has a tropism for many human organs and tissues. Nevertheless, such multiorgan distribution in cadaver tissues does not mean that infected people had developed the disease during their lifetime, nor is it related to disease severity. For this reason, matching molecular investigation results with any detectable anatomical damage by histological analyses of infected tissues is essential, and this is the subject of an ongoing study by the authors. Certainly, the ubiquitous post-mortem presence of SARS-CoV-2 even a long time after death and also in bodies subjected to burial and/or refrigeration is an extraordinary result, demonstrating the high resistance of this coronavirus to uncomfortable environmental conditions.

However, these results must be treated with caution, not only because positive molecular investigations for coronaviruses are not automatically diagnostic of coronavirus disease, but also and above all because they do not always define the main cause of death. Therefore, without contextual histological investigations or when the results of histological investigations are compromised by partial cadaveric decomposition or by advanced putrefaction, the positivity of post-mortem molecular analyses should not lead pathologists to conclude that COVID-19 was the cause of death, especially due to the consequences that such improper conclusions could have in medico-legal disputes.

\section{Key points}

1. The SARS-CoV-2 virus has strong persistence in the external environment, especially at low temperatures, and it could still be contagious on inanimate surfaces.

2. A large amount of virus may remain in deceased people infected with SARS-CoV-2 even a long time after death and also in bodies subjected to burial and/or refrigeration. The survival time of the virus may even be prolonged in refrigerated cadavers thanks to its resistance to cold environments.

3. The ubiquitous post-mortem presence of SARS-CoV-2 RNA demonstrates that SARS-CoV-2 infection is characterized by a multiorgan distribution, thanks to virus tropism for many human organs and tissues.

4. The suspected risk to health professionals of COVID-19 infection from an individual whose death resulted from COVID-19 should not be overlooked.

Funding Open access funding provided by Università degli Studi di Bari Aldo Moro within the CRUI-CARE Agreement.

Open Access This article is licensed under a Creative Commons Attribution 4.0 International License, which permits use, sharing, adaptation, distribution and reproduction in any medium or format, as long as you give appropriate credit to the original author(s) and the source, provide a link to the Creative Commons licence, and indicate if changes were made. The images or other third party material in this article are included in the article's Creative Commons licence, unless indicated otherwise in a credit line to the material. If material is not included in the article's Creative Commons licence and your intended use is not permitted by statutory regulation or exceeds the permitted use, you will need to obtain permission directly from the copyright holder. To view a copy of this licence, visit http://creativecommons.org/licenses/by/4.0/.

\section{References}

1. World Health Organization. Coronavirus Disease Situation Report: Weekly epidemiological update - 22 December 2020. https://www. who.int/publications/m/item/weekly-epidemiological-update---22december-2020.

2. Hui PYK. Tropism, replication competence, and innate immune responses of the coronavirus SARS-CoV-2 in human respiratory tract and conjunctiva: an analysis in ex-vivo and in-vitro cultures. Lancet Respir Med. 2020;8:687-95.

3. Solarino B, Ferorelli D, Dell'Erba A. Post-mortem routine practice in the era of the COVID-19 pandemic. J Forensic Leg Med. 2020;74:102010.

4. Hanley B, Lucas SB, Youd E, Swift B, Osborn M. Autopsy in suspected COVID-19 cases. J Clin Pathol. 2020;73:239-42.

5. Edler C, Schroder AS, Aepfelbacher M, Fitzek A, Heinemann A, Heinrich F, et al. Erratum: Correction to: Dying with SARSCoV-2 infection-an autopsy study of the first consecutive 80 cases in Hamburg. Germany Int J Legal Med. 2020;134:1977.

6. Kampf G. Persistence of coronaviruses on inanimate surfaces and their inactivation with biocidal agents. J Hosp Infect. 2020;104:246-51.

7. Beltempo P, Curti SM, Maserati R, Gherardi M, Castelli M. Persistence of SARS-CoV-2 RNA in post-mortem swab 35 days after death: A case report. Forensic Sci Int. 2021;319:110653.

8. Dahdouh E, Lazaro-Perona F, Romero-Gomez MP, Mingorance J, Garcia-Rodriguez J. Ct values from SARS-CoV-2 diagnostic PCR assays should not be used as direct estimates of viral load. $\mathrm{J}$ Infect. 2021;3:45.

9. Huang CG, Lee KM, Hsiao MJ, Yang SL, Huang PN, Gong YN, et al. Culture-based virus isolation to evaluate potential infectivity of clinical specimens tested for COVID-19. J Clin Microbiol. 2020;58:e01068-e1120.

10. Singanayagam A, Patel M, Charlett A, Bernal JL, Saliba V, Ellis $\mathrm{J}$, et al. Duration of infectiousness and correlation with RT-PCR cycle threshold values in cases of COVID-19, England, January to May 2020. Euro Surveill. 2020;25:2001483.

11. Weiss SR. Forty years with coronaviruses. J Exp Med. 2020;217:e20200537.

12. Coronaviridae Study Group of the International Committee on Taxonomy of Viruses, Gorbalenya AE, Baker SC, et al. The species severe acute respiratory syndrome-related coronavirus: classifying 2019-nCoV and naming it SARS-CoV-2. Nat Microbiol. 2020;5:536-44.

13. Meo SA, Alhowikan AM, Al-Khlaiwi T, Meo IM, Halepoto DM, Iqbal M, et al. Novel coronavirus 2019-nCoV: prevalence, biological and clinical characteristics comparison with SARS-CoV and MERS-CoV. Eur Rev Med Pharmacol Sci. 2020;24:2012-9.

14. Shidham VB, Frisch NK, Layfield LJ. Severe acute respiratory syndrome coronavirus 2 (the cause of COVID 19) in different types of clinical specimens and implications for cytopathology specimen: an editorial review with recommendations. Cyto J. 2020;17:7.

15. Peeri NC, Shrestha N, Rahman MS, Zaki R, Tan Z, Bibi S, et al. The SARS, MERS and novel coronavirus (COVID-19) epidemics, 
the newest and biggest global health threats: what lessons have we learned? Int J Epidemiol. 2020;49:717-26.

16. World Health Organization. Infection prevention and control for the safe management of a dead body in the context of COVID-19: interim guidance. 2020. https://apps.who.int/iris/bitstream/handle/ 10665/331538/WHO-COVID-19-1PC_DBMgmt-2020.1-eng.pdf. Accessed 1 February 2021.

17. International Federation of Associations of Anatomists (IFAA). Best practice guidelines for body donation programmes during the novel Coronavirus pandemic. 2020. http://www.ifaa.net/wpcontent/uploads/2020/05/IFAA-Staement-on-COVID-19_-finalv2.pdf. Accessed 1 February 2021.

18. Italian Ministry of Health. Emergency indications related to the COVID-19 epidemic concerning the funeral, cemetery and cremation sector. https://www.regione.umbria.it/documents/18/20018559/ Circolare+servizi+funebri+e+gestione+salme/18b8af5b-2a0c4b8e-b4c9-95bd9575330b. Accessed 1 Apr 2020.

19. Xu Z, Shi L, Wang Y, Zhang J, Huang L, Zhang C, et al. Pathological findings of COVID-19 associated with acute respiratory distress syndrome. Lancet Respir Med. 2020;8:420-2.

20. De Cock KM, Zielinski-Gutierrez E, Lucas SB. Learning from the dead. N Engl J Med. 2019;381:1889-91.

21. Baj J, Ciesielka M, Buszewicz G, Maciejewski R, Budzynska B Listos P, et al. COVID-19 in the autopsy room-requirements, safety, recommendations and pathological findings. Forensic Sci Med Pathol. 2021;17:101-13.

22. Burton J. Health and safety of necropsy. J Clin Pathol. 2003;56:254-60.

23. Osborn M, Lucas S, Stewart, R, Swift B, Youd E. The Royal College of Pathologists. Autopsy practice relating to possible cases of COVID-19 (2019-nCov, Novel Coronavirus from China 2019/2020). https://www.rcpath.org/uploads/assets/d5e28baf-5789-4b0facecfe370eee6223/fe8fa85a-f0044a0c-81ee4b2b9cd12cbf/Briefingon-COVID-19-autopsy-Feb-2020.pdf. Accessed 12 December 2020.

24. European Centre for Disease Prevention and Control (ECDC). Considerations related to the safe handling of bodies of deceased persons with suspected or confirmed COVID-19. 2020. https:// www.ecdc.europa.eu/sites/default/files/documents/COVID-19safe-handling-of-bodies-or-persons-dying-from-COVID19.pdf. Accessed 12 December 2020.

25. Hoffman PN, Healing TD. International Society for Infectious Diseases United States. The infection hazards of human cadavers. Guide to infection control in the healthcare setting. https:// isid.org/guide/infectionprevention/humancadavers/. Accessed 15 January 2021.

26. Kampf G, Todt D, Pfaender S, Steinmann E. Persistence of coronaviruses on inanimate surfaces and their inactivation with biocidal agents. J Hosp Infect. 2020;104:246-51.

27. Wang XW, Li JS, Jin M, Zhen B, Kong QX, Song N, et al. Study on the resistance of severe acute respiratory syndrome-associated coronavirus. J Virol Methods. 2005;126:171-7.

28. Riddell S, Goldie S, Hill A, Eagles D, Drew TW. The effect of temperature on persistence of SARS-CoV-2 on common surfaces. Virol J. 2020;17:145.
29. Pagat AM, Seux-Goepfert R, Lutsch C, Lecouturier V, Saluzzo JF, Kusters IC. Evaluation of SARS-Coronavirus decontamination procedures. Appl Biosaf. 2007;12:100-8.

30. Mao DM, Zhou N, Zheng D, Yue JC, Zhao QH, Luo B, et al. Guide to forensic pathology practice for death cases related to coronavirus disease 2019 (COVID-19), (Trial draft). Forensic Sci Res. 2020;5:1-7.

31. Darnell ME, Subbarao K, Feinstone SM, Taylor DR. Inactivation of the coronavirus that induces severe acute respiratory syndrome, SARS-CoV. J Virol Methods. 2004;121:85-91.

32. Henwood AF. Coronavirus disinfection in histopathology. J Histotechnol. 2020;43:102-4.

33. Camero K. Can you catch coronavirus from a dead body? It's a possibility, researchers say. Florida, United States: Miami Herald; 2020. https://www.miamiherald.com/news/coronavirus/ article242085146.html. Accessed 10 Sep 2020.

34. Heinrich F, Meißner K, Langenwalder F, Püschel K, Nörz D, Hoffmann A, et al. Postmortem stability of SARS-CoV-2 in nasopharyngeal mucosa. Emerg Infect Dis. 2021;27:329-31.

35. Centers for disease control and prevention. Coronavirus disease 2019 (COVID-19): collection and submission of postmortem specimens from deceased persons with known or suspected COVID19. 2020. Interim guidance. https://www.cdc.gov/coronavirus/ 2019-ncov/hcp/guidance-postmortemspecimens.html. Accessed 1 February 2021.

36. Aljerian K, BaHammam AS. COVID-19: lessons in laboratory medicine, pathology, and autopsy. Ann Thorac Med. 2020;15:138-45.

37. Santurro A, Scopetti M, D'Errico S, Fineschi V. A technical report from the Italian SARS-CoV-2 outbreak. Postmortem sampling and autopsy investigation in cases of suspected or probable COVID19. Forensic Sci Med Pathol. 2020;16:471-6.

38. Sriwijitalai W, Wiwanitkit V. COVID-19 in forensic medicine unit personnel: observation from Thailand. J Forensic Leg Med. 2020;72:101964.

39. Na JY, Noh SJ, Choi MS, Park JP. Standard operating procedure for post-mortem inspection in a focus on coronavirus disease-19: the Korean Society for Legal Medicine. J Korean Med Sci. 2020;35:e302.

40. Khoo LS, Hasmi AH, Ibrahim MA, Mahmood MS. Management of the dead during COVID-19 outbreak in Malaysia. Forensic Sci Med Pathol. 2020;16:463-70.

41. Finegan O, Fonseca S, Guyomarc'h P, Morcillo Mendez MD, Rodriguez Gonzalez J, Tidball-Binz M, et al. International Committee of the Red Cross (ICRC): general guidance for the management of the dead related to COVID-19. Forensic Sci Int Synergy. 2020;2:129-37.

Publisher's Note Springer Nature remains neutral with regard to jurisdictional claims in published maps and institutional affiliations. 